\title{
In Vitro Plant Multiplication from Rhizomes of Turmeric (Curcuma domestica Val.) and Temoe Lawak (C. xanthoriza Roxb.)
}

\author{
Zurhan MuKhR** and Hikoyuki YamaGuchI \\ Laboratory of Radiation Genetics, Faculty of Agriculture, \\ University of Tokyo, Yayoi 1-1-1, Bunkyo-ku, Tokyo 113, Japan
}

(Received November 27, 1985)

(Accepted December 21, 1985)

Turmeric (Curcuma domestica Val. =C. longa L., Zingiberaceae) and "temoe lawak" $(C$. xanthoriza Roxb., Zingiberaceae) are generally used as traditional medicine in Indonesia. In India, Srinivasan ${ }^{1)}$ studied the content of curcuminoids in turmeric by chromatography. Srimal and Dhawan ${ }^{2)}$ investigated the pharmacology of curcumin contained in turmeric and proved that curcumin has anti-inflammatory activity, returning the levels of the serum glutamic oxaloacetic transaminase and serum glutamic pyruvic transaminase to normal after its administration to inflamed rats.

In recent years a large scale propagation of plants has been developed by use of the tissue culture technique, and the number of plant species being enabled to multiply by this technique increases annually.

In Zingiberaceae, Hosoki and Sagawa ${ }^{3)}$ have succeeded for the first time in a clonal propagation of ginger (Zingiber officinale Roscue) by culture in vitro on the medium of Murashige and Skoog supplemented with minor elements and vitamins. While a rapid clonal propagation of Curcuma species has been desired because of the slow-to-multiply species, there has been no report on tissue culture work on this species.

The present paper describes the micropropagation of plants of two Curcuma species, $C$. domestica and C. xanthoriza, by the technique of tissue culture.

\section{Materials and Methods}

Rhizomes of $C$. domestica Val. and $C$. xanthoriza Roxb. were bought in the common market of Bandung, Indonesia, and then brought to the Laboratory of Radiation Genetics and Chemical Mutagenesis, Faculty of Agriculture, University of Tokyo. They were washed repeatedly with detergent and tap water. Buds which emerged on rhizomes were excised, and their surface was sterilized by immersing in $70 \%$ ethanol for 2 min and then in $0.5 \%$ sodium hypochlorite (10\% Chlorox) for $10 \mathrm{~min}$. After removing a few scale leaves and the basal part, they were immersed in $2 \%$ Purelox solution for $5 \mathrm{~min}$ and washed three times with sterile distilled water. Buds trimmed in 2 to $3 \mathrm{~mm}$ height were cultured on the medium of Ringe and Nitsch ${ }^{4}$ with $2 \%$ sucrose, $0.8 \%$ agar and supplemented with 6-benzyladenine (BA), naphthalene acetic acid (NAA) and/or 2,4-dichlorophenoxyacetic acid (2, 4-D). The pH of the media was adjusted to

* Present address: Radiation Biology Section, Research Centre for Nuclear Techniques, NAEA, J1. Tamansari No. 71, Bandung, Indonesia. 
6.0 with $\mathrm{KOH}$ or $\mathrm{HCl}$ prior to the addition of agar, followed by autoclaving $\left(10.4 \times 10^{4} \mathrm{~Pa}\right.$ at $121^{\circ} \mathrm{C}$ for $15 \mathrm{~min}$ ).

The buds were grown in vitro at $25 \pm 1^{\circ} \mathrm{C}$ in the dark. After formation of root or embryoid they were transferred into the growth chamber (Koitotron) and maintained for $12 \mathrm{hr}$ under light of about 600 to 1,200 lux and for another $12 \mathrm{hr}$ in the dark at $25 \pm 1^{\circ} \mathrm{C}$ in order to stimulate shoot formation.

\section{Results}

In this experiment most of the explants were contaminated with fungi, and thus three to four days after innoculation the contaminated explants were sterilized again and recultured. Even after such treatment, a few buds were still infected. Explants grown on the basal medium did not form either shoots, roots or calluses. This result was similar to ginger experiment. ${ }^{3)}$

\section{Curcuma domestica}

Explants grown on the medium containing $1.0 \mathrm{mg} / \mathrm{l} \mathrm{BA}$ formed shoots and roots while those cultured on the medium with $10 \mathrm{mg} / l \mathrm{BA}$ and $1 \mathrm{mg} / l 2$, 4-D or the medium with $10 \mathrm{mg} / l \mathrm{BA}$ and $15 \mathrm{mg} / l$ NAA produced calluses. If calluses were transferred on the medium with $1 \mathrm{mg} / l$ BA and $1 \mathrm{mg} / l \mathrm{NAA}$ a shoot and auxiliary shoots were formed.

Explants cultured on the medium containing $10 \mathrm{mg} / l$ BA in combination with $15 \mathrm{mg} / l \mathrm{NAA}$ produced calluses, embryoids and roots. When they were recultured on the medium with $10 \mathrm{mg} / \mathrm{l} \mathrm{BA}$ and grown in the Koitotron, shoots were formed.

\section{Curcuma xanthoriza}

Buds grown on the medium containing $1 \mathrm{mg} / l \mathrm{BA}$ and $1 \mathrm{mg} / l \mathrm{NAA}$ formed roots and shoots. Explants cultured on the medium supplemented with $10 \mathrm{mg} / l$ BA produced roots and lateral buds. When the buds were grown on the medium enriched with $10 \mathrm{mg} / l \mathrm{BA}$ and $15 \mathrm{mg} / l \mathrm{NAA}$, calluses were induced. If these calluses were transferred to the basal medium, roots were formed.

In order to study the effect of hormones, 2, 4-D and BA, on callus and organ formation, the precultured materials were transferred onto the medium supplemented with 2, 4-D of $0,0.5$, $1 \mathrm{mg} / l$ in combination with BA of 0 and $1 \mathrm{mg} / l$. The results are shown in Table 1. Materials harvested from the medium supplemented with $10 \mathrm{mg} / l \mathrm{BA}$ and $15 \mathrm{mg} / l \mathrm{NAA}$ did not dif-

Table 1. Effect of 2, 4-D and BA on the recultured $C$. xanthoriza.

\begin{tabular}{|c|c|c|c|c|c|}
\hline \multicolumn{2}{|c|}{ Material } & \multirow{2}{*}{$C(1)$} & \multirow{2}{*}{ CERS (2) } & \multirow{2}{*}{ CERS (3) } & \multirow{2}{*}{ CERS (4) } \\
\hline 2, 4-D & $\mathrm{BA}(\mathrm{mg} / l)$ & & & & \\
\hline 0 & 0 & $\mathbf{R}$ & $\mathrm{CR}$ & $\mathrm{CR}$ & $\mathrm{R}$ \\
\hline 0.5 & 0 & $\mathrm{C}$ & CES & ES & ES \\
\hline 1 & 0 & $\mathrm{C}$ & S & $\mathrm{S}$ & $\mathrm{S}$ \\
\hline 0 & 1 & $\mathrm{C}$ & CE & $\mathrm{S}$ & $\mathrm{S}$ \\
\hline 0.5 & 1 & $\mathrm{C}$ & CES & CES & none \\
\hline 1 & 1 & $\mathrm{C}$ & ES & $\mathrm{S}$ & $\mathrm{E}$ \\
\hline
\end{tabular}

C: callus, E: embryoid, R: root, S: shoot.

(1) materials harvested from the medium supplemented with $10 \mathrm{mg} / l \mathrm{BA}$ and $15 \mathrm{mg} / l \mathrm{NAA}$.

(2) materials harvested from the medium supplemented with $1 \mathrm{mg} / l \mathrm{BA}$ and $1 \mathrm{mg} / l 2$, 4-D.

(3) materials harvested from the medium supplemented with $10 \mathrm{mg} / l$ BA.

(4) materials harvested from the medium supplemented with $1 \mathrm{mg} / l \mathrm{BA}$ and $1 \mathrm{mg} / l \mathrm{NAA}$. 
ferentiate any organ, except root formation after transferring to the basal medium. The globular embryoids were multiplied on the freshly prepared medium containing $1 \mathrm{mg} / l \mathrm{BA}$ when the materials first cultured on the medium with $1 \mathrm{mg} / l$ 2, 4-D and $1 \mathrm{mg} / l \mathrm{BA}$ were transferred.

\title{
Discussion
}

Tissue culture has been used to accelerate plantation development, to shorten the breeding cycle, and to rapidly multiply and disseminate limited materials even for the slow-to-propagate species. ${ }^{5,6)}$

In this experiment, proliferating embryoids and roots from a bud of rhizome were successfully obtained by the tissue culture technique in vegetatively propagating Curcuma species. This paper is the first report demonstrating the possibility of a rapid and large scale propagation of a clone by the culture of a bud from the rhizome of Curcuma plant. Because the plants obtained by the technique used here are expected to be pathogen free, it adds a useful information to the agricultural industry and medicinal plants.

This work was carried out by a fellowship of the International Atomic Energy Agency to Z. M.

\section{References}

1) Srinivasan, K. R., 1953. J. Pharm. Pharmacol., 5: 448-457.

2) Srimal, R. C., B. N. Dhawan, 1973. J. Pharm. Pharmacol., 5: 448-457.

3) Hosoki, T., Y. Sagawa, 1977. Hort. Sc., 12: 451-452.

4) Ringe, F., J. P. Nitsch, 1968. Plant Cell Physiol., 9: 639-652.

5) Evans, D. A., W. R. Sharp, 1982. In "Application of Plant Cell and Tissue Culture to Agriculture \& Industry” (ed. by Tomes, D. T., B. E. Ellis, P. M. Harney, K. J. Kasha, R. L. Peterson), p. 209231, University of Guelph, Ontario, Canada.

6) Lane, W. D., 1982. In "Application of Plant Cell and Tissue Culture to Agriculture \& Industry" (ed. by Tomes, D. T., B. E. Ellis, P. M. Harney, K. J. Kasha, R. L. Peterson), p. 163-186, University of Guelph, Ontario, Canada.

\section{《和文要約》}

\section{ウコン (Curcuma domestica Val.) とクスリウコン (C. xanthoriza Roxb.)の 根茎培養による大量増殖}

\author{
Zurhan Mukhri, 山口彦之 \\ 東京大学農学部放射線遺伝学教室
}

\footnotetext{
ショウガ科汇属するウコンとクスリウコンは根茎によって繁殖する多年生草本であるが，その増殖率 は低い. それらの植物の根茎から仮軸分枝芽を切り出し, 培養した. 6-ベンジルアデニン, ナフタレン 酢酸, 2, 4-D を添加した Ringe·Nitsch 培地で, カルス, 苗条, 根を発生させることができた. 培地の 選択によってウコンとクスリウコンの根茎から大量の種苗を生産することが可能である.
} 